\title{
Sylwia Górniak
}

Uniwersytet im. Adama Mickiewicza w Poznaniu

Wydziat Nauk Geograficznych $i$ Geologicznych

\section{Aktywność i skuteczność gmin powiatu konińskiego w pozyskiwaniu środków z Wielkopolskiego Regionalnego Programu Operacyjnego w latach 2007-2013 na realizację zadań własnych samorządu lokalnego ${ }^{1}$}

\begin{abstract}
Zarys treści: Integracja Polski z Unią Europejską stworzyła dla samorządów gminnych niepowtarzalną szansę na uzupełnienie braków występujących w budżetach lokalnych. Możliwości i korzyści plynące z wykorzystania środków europejskich na realizację wielu kosztownych przedsięwzięć spowodowały wzrost zainteresowania gmin ich pozyskaniem. Celem pracy jest identyfikacja zróżnicowania aktywności i skuteczności gmin powiatu konińskiego w pozyskiwaniu środków z Wielkopolskiego Regionalnego Programu Operacyjnego (WRPO). Analiza uwzględnia lata 2007-2013 i obejmuje swym zakresem 14 gmin powiatu konińskiego. Przeprowadzono ją w odniesieniu do zadań własnych gmin, co pozwoliło zidentyfikować główne kierunki wsparcia udzielonego gminom z tego programu operacyjnego.
\end{abstract}

Słowa kluczowe: Wielkopolski Regionalny Program Operacyjny, fundusze strukturalne, zadania gmin, powiat koniński

\section{Wstęp}

Przystąpienie Polski do Unii Europejskiej w 2004 r. stworzyło dla samorządów gminnych niepowtarzalną szansę pozyskania dodatkowych środków finansowych na realizację wielu kosztownych przedsięwzięć z obszaru szeroko rozumianego rozwoju lokalnego. Dużą rolę w tym zakresie odgrywały funkcjonujące

1 Artykuł napisany na podstawie pracy magisterskiej pt. „Rola środków Wielkopolskiego Regionalnego Programu Operacyjnego w finansowaniu zadań własnych gmin powiatu konińskiego w latach 2007-2013", przygotowanej w Zakładzie Analizy Regionalnej IGSEiGP pod kierunkiem prof. UAM dr. hab. Pawła Churskiego. 
w ramach polityki spójności fundusze strukturalne, które ze względu na niższe koszty pozyskania oraz bezzwrotny charakter stanowiły bardzo atrakcyjne źródło finansowania wielu spoczywających na gminach zadań (por. Misterek 2008, Churski 2014). Szeroki zakres zadań, który nakłada na nie ustawa o samorządzie gminnym² nierzadko przekracza ich ograniczone moźliwości finansowe ${ }^{3}$, dlatego gminy coraz częściej poszukują dodatkowych środków. Możliwości i korzyści płynące z wykorzystania funduszy strukturalnych na wykonanie projektów gminnych spowodowały wzrost zainteresowania ich pozyskaniem. Samorządy gminne wykazały szczególnie duże zainteresowanie środkami funkcjonującymi w latach 2007-2013 w ramach Regionalnych Programów Operacyjnych (mających na celu wzrost konkurencyjności regionów i promowanie zrównoważonego rozwoju przez stworzenie właściwych warunków dla wzrostu inwestycji na poziomie lokalnym i regionalnym), czego potwierdzeniem może być fakt, że samorządy stanowiły największą i najbardziej aktywną grupę ich beneficjentów (por. Kuchlewski i in. 2007, Churski 2008). Wysoki stopień aktywności gmin w aplikacji o fundusze unijne często nie przekłada sięjednak na skuteczność podjętych przez nie starań, co może wynikać ze złożoności procedury wyboru wniosków do dofinansowania. Złożenie wniosku w ramach konkursu jest bowiem początkową fazą, po której następuje rozbudowany etap jego oceny. Każdy wniosek podlega ocenie formalnej, dotyczącej zazwyczaj spełnienia przez niego podstawowych warunków technicznych w zakresie kwalifikowalności beneficjenta i projektu. Spełnienie tych kryteriów jest warunkiem niezbędnym do dalszego rozpatrywania wniosku umożliwia (bardziej złożoną) ocenę merytoryczną wniosku, dotyczącą najczęściej określonych zapisów projektu. Wynikiem tej oceny jest utworzenie listy rankingowej projektów, szeregującej je według liczby zdobytych w ocenie merytorycznej punktów. W zależności od dostępnej w ramach konkursu puli środków i wartości projektów dofinansowanie przyznawane jest projektom z kolejnych miejsc na liście rankingowej - na podstawie zawartej umowy o dofinansowanie (por. Sztorc $\mathrm{i}$ in. 2011).

Celem pracy jest identyfikacja zróżnicowania aktywności i skuteczności gmin powiatu konińskiego w pozyskiwaniu środków z Wielkopolskiego Regionalnego Programu Operacyjnego (WRPO). Analiza uwzględnia lata 2007-2013 i obejmuje swym zakresem 14 gmin położonego we wschodniej części Wielkopolski powiatu konińskiego: Golina, Grodziec, Kazimierz Biskupi, Kleczew, Kramsk, Krzymów, Rychwał, Rzgów, Skulsk, Sompolno, Stare Miasto, Ślesin, Wierzbinek i Wilczyn. Ocenę aktywności i skuteczności podjętych przez gminy starań pozyskania środków z WRPO przeprowadzono w odniesieniu do zadań własnych gmin, co pozwoliło zidentyfikować główne kierunki wsparcia udzielanego im w ramach tego programu operacyjnego. W artykule wykorzystano dane dostępne w Systemie Informatycznym Monitoringu i Kontroli (SIMIK) oraz informacje z urzędów gmin, które pozyskano w drodze badań bezpośrednich przeprowadzonych w okresie czerwiec-listopad 2014 r.

Dz.U. z 1990 r. nr 16, poz. 95 z późn. zm.

Ograniczone możliwości finansowe samorządów terytorialnych potwierdzają wyniki badań przeprowadzonych m.in. przez Motka (2006). 


\section{Zadania własne samorządów gminnych w Polsce}

Samorządy gminne wykonują szeroki katalog zadań publicznych, wśród których podstawową grupę stanowią zadania własne, mające na celu zaspokojenie potrzeb zamieszkującej na ich obszarze społeczności lokalnej. Wśród nich wyróżnia się zadania obligatoryjne - wykonywane w zakresie określonym w ustawie ${ }^{4}$, oraz zadania fakultatywne - określane w uchwale organu stanowiącego. Wykonywane są one $w$ ramach posiadanych przez samorządy własnych możliwości finansowych, na własny rachunek i odpowiedzialność, co oznacza, że gminy dysponują znaczną swobodą co do sposobu ich realizacji i wydatkowania środków finansowych (por. Jastrzębska 2012).

W literaturze przedmiotu znaleźć można szereg różnych systematyzacji zadań własnych gmin, których punktem wyjścia są najczęściej zadania własne określone w ustawie o samorządzie gminnym z dnia 8 marca $1990 \mathrm{r}^{5}$ (wymienia ona $20 \mathrm{za}$ dań własnych gmin). Wśród nich wyróżnić można klasyfikację Niewiadomskiego (2001), grupującą zapisane w tej ustawie zadania w cztery zasadnicze kategorie, a także systematyzację Leońskiego (2002), wydzielającą 10 grup zadań własnych gmin. W oparciu o powyższe klasyfikacje dokonano systematyzacji zadań własnych samorządów gminnych, którą wykorzystano w tej pracy do analizy kierunków absorpcji środków pochodzących z WRPO. Systematyzacja ta wyodrębnia zadania z zakresu:

1. infrastruktury drogowej (w tym m.in.: budowa dróg, ścieżek rowerowych, chodników, transport publiczny, uzbrojenie terenów inwestycyjnych),

2. infrastruktury i usług społecznych (w tym m.in.: szkolnictwo, ochrona zdrowia, pomoc społeczna, obiekty administracji publicznej),

3. ochrony środowiska (w tym m.in.: budowa kanalizacji, wodociągów, urządzeń sanitarnych, gospodarka odpadami),

4. turystyki i kultury (w tym m.in.: budowa obiektów i urządzeń turystycznych, tworzenie szlaków turystycznych, promocja gminy, organizacja wydarzeń kulturalnych),

5. ładu przestrzennego i ekologicznego (w tym m.in.: rewitalizacja obszarów zdegradowanych, planowanie przestrzenne, zieleń gminna).

\section{Aktywność gmin powiatu konińskiego w pozyskiwaniu środków z WRPO}

Analiza aktywności gmin powiatu konińskiego w pozyskiwaniu środków dostępnych w latach 2007-2013 w ramach WRPO uwzględnia ogólną liczbę i wartość złożonych przez nie wniosków o dofinansowanie, liczbę wniosków złożonych w poszczególnych kategoriach zadań oraz udział kwoty wnioskowanego dofinan-

$4 \quad$ Ustawa o samorządzie gminnym z dnia 8 marca $1990 \mathrm{r}$.

5 Dz.U. $1990 \mathrm{nr} 16$, poz. 95 z późn. zm. 
sowania w danej kategorii zadań w ogólnej wartości wsparcia, które starały się one pozyskać z WRPO.

W latach 2007-2013 wszystkie gminy powiatu konińskiego wykazały zainteresowanie pozyskaniem środków z WRPO - łącznie złożyły one 39 wniosków o dofinansowanie. Najwyższą aktywnością wśród nich wykazała się gmina Stare Miasto, która złożyła największą liczbę wniosków o dofinansowanie - sześć (patrz tab. 1). Również Rychwał i Ślesin charakteryzowały się stosunkowo wysoką aktywnością w tym zakresie i podjęły próbę pozyskania wsparcia z WRPO na realizację czterech projektów. Najniższą aktywność mierzoną liczbą złożonych wniosków o dofinansowanie odnotowały natomiast: Grodziec, Krzymów i Rzgów, które złożyły po jednym wniosku o dofinansowanie, a także Skulsk i Wierzbinek, które podjęły próbę pozyskania środków na realizację dwóch projektów. Aktywność pozostałych gmin badanego powiatu: Golina, Kazimierz Biskupi, Kleczew, Kramsk, Sompolno i Wilczyn, ograniczyła się natomiast do złożenia trzech wniosków o dofinansowanie z WRPO.

Aktywność gmin powiatu konińskiego w aplikacji o środki z WRPO, określona wartością dofinansowania, którą starały się one pozyskać na realizację projektów, w dużej mierze wynikała z liczby złożonych przez nie wniosków o dofinansowanie. Najwyższą aktywnością pod tym względem cechowała się gmina Stare Miasto, która w latach 2007-2013 starała się pozyskać z WRPO dofinansowanie w wysokości niemal 15 mln zł. Względnie wysoką aktywnością wykazały się także: Kleczew, Rychwał i Golina, które na realizację planowanych działań starały się pozyskać kwotę rzędu 9,5-11,0 mln zł. Gminy: Sompolno, Kramsk, Krzymów i Ślesin podjęły natomiast próbę pozyskania kwoty dofinansowania oscylującej w granicach 6,7-8,8 mln zł. Pozostałe analizowane jednostki samorządu lokalnego wykazały się dużo niższą aktywnością (patrz ryc. 1). W przypadku gmin: Wilczyn i Wierzbinek łączna wartość wnioskowanego wsparcia z WRPO oscylowała w przedziale 1,1-3,4 mln zł, zaś w gminach: Grodziec, Kazimierz Biskupi, Skulsk i Rzgów nie przekraczała poziomu $1 \mathrm{mln}$ zł - wynosiła od 540 tys. zł do ponad 850 tys. zł.

Aktywność gmin w absorpcji środków z WRPO kształtowała się na różnym poziomie w poszczególnych kategoriach zadań. W latach 2007-2013 gminy powiatu konińskiego wykazały największe zainteresowanie pozyskaniem środków na realizację zadań mających na celu uzupełnienie braków w infrastrukturze drogowej. Względnie duże znaczenie miało dla nich także pozyskanie środków na realizację działań z zakresu ochrony środowiska, infrastruktury i usług społecznych oraz turystyki i kultury, które z uwagi na wysokie koszty często przekraczały ich możliwości finansowe. Najniższe zainteresowanie analizowanych gmin odnotowano natomiast w kategorii zadań związanych z ładem przestrzennym i ekologicznym.

Liczba złożonych przez gminy powiatu konińskiego wniosków z zakresu infrastruktury drogowej (głównie na budowę dróg i uzbrojenie terenów inwestycyjnych) stanowiła 43,6\% ogólnej liczby złożonych przez nie wniosków o wsparcie z WRPO. Udział kwoty dofinansowania, którą starały się one pozyskać na te projekty, w ogólnej kwocie wnioskowanego przez nie wsparcia osiągał wartość $20,6 \%$. Starania pozyskania środków na realizację inwestycji drogowych podję- 
Tabela 1. Aktywność gmin powiatu konińskiego w pozyskiwaniu środków z WRPO w latach 2007-2013

\begin{tabular}{|c|c|c|c|c|}
\hline Gmina & Nazwa projektu & Kategoria zadań & $\begin{array}{l}\text { Wartość } \\
\text { projektu } \\
(\mathrm{w} \mathrm{zl})\end{array}$ & $\begin{array}{l}\text { Wartość wniosko- } \\
\text { wanego dofinan- } \\
\text { sowania (w zl) }\end{array}$ \\
\hline \multirow[t]{3}{*}{ Golina } & $\begin{array}{l}\text { Budowa sali sportowej z widownią do } 200 \text { miejsc przy gimnazjum } \\
\text { w Golinie. }\end{array}$ & $\begin{array}{l}\text { Infrastruktura i usługi spo- } \\
\text { leczne }\end{array}$ & 6551400,00 & 4910000,00 \\
\hline & Obwodnica północno-zachodnia Goliny - droga gminna. & Infrastruktura drogowa & 3804116,24 & 1095421,13 \\
\hline & $\begin{array}{l}\text { Remont XIX-wiecznego dworu z przeznaczeniem na cele spoleczno- } \\
\text {-kulturalne wraz z rewaloryzacją zabytkowego parku dworskiego } \\
\text { w Golinie. }\end{array}$ & Turystyka i kultura & 5252100,00 & 3670167,48 \\
\hline Grodziec & Budowa dróg gminnych Królików-Biala Kolonia-Biala-Bystrzyca. & Infrastruktura drogowa & 2226204,54 & 855237,34 \\
\hline \multirow[t]{3}{*}{$\begin{array}{l}\text { Kazimierz } \\
\text { Biskupi }\end{array}$} & $\begin{array}{l}\text { Centrum Edukacji Ekologicznej o Puszczy Bieniszewskiej w Kazimie- } \\
\text { rzu Biskupim. }\end{array}$ & Ochrona środowiska & 233886,70 & 156134,02 \\
\hline & Przebudowa drogi Wola Łaszczowa-Sokólki. & Infrastruktura drogowa & 1115406,44 & 454925,29 \\
\hline & $\begin{array}{l}\text { Wyposażenie Centrum Edukacji Ekologicznej o Puszczy Bieniszew- } \\
\text { skiej w Kazimierzu Biskupim. }\end{array}$ & Ochrona środowiska & 179424,85 & 109624,03 \\
\hline \multirow[t]{3}{*}{ Kleczew } & Budowa oczyszczalni ścieków i kanalizacji sanitarnej w Kleczewie. & Ochrona środowiska & 12379933,79 & 6451730,17 \\
\hline & Przebudowa ul. 50-lecia KWB „Konin” w Kleczewie. & Infrastruktura drogowa & 1501343,54 & 1201074,83 \\
\hline & Rewitalizacja terenów pogórniczych wokół jeziora w gminie Kleczew. & Ład przestrzenny i ekologiczny & 4763438,71 & 3274230,81 \\
\hline \multirow[t]{3}{*}{ Kramsk } & $\begin{array}{l}\text { Budowa szkoły podstawowej z aulą i salą gimnastyczną w Woli Pod- } \\
\text { łężnej - gmina Kramsk. }\end{array}$ & $\begin{array}{l}\text { Infrastruktura i usługi spo- } \\
\text { leczne }\end{array}$ & 4626634,02 & 3469975,51 \\
\hline & Przebudowa drogi gminnej w miejscowości Ksawerów. & Infrastruktura drogowa & 728624,08 & 364312,04 \\
\hline & $\begin{array}{l}\text { Uzbrojenie terenu inwestycyjnego Kramsk - Łęgi i Wielany w gminie } \\
\text { Kramsk. }\end{array}$ & Infrastruktura drogowa & 6131501,62 & 3985476,05 \\
\hline Krzymów & $\begin{array}{l}\text { Budowa kanalizacji sanitarnej części zachodniej aglomeracji Krzy- } \\
\text { mów. }\end{array}$ & Ochrona środowiska & 17928507,16 & 7590836,47 \\
\hline \multirow[t]{4}{*}{ Rychwał } & $\begin{array}{l}\text { Budowa drogi gminnej na odcinku Dąbroszyn-Grabowa-Jaroszewice } \\
\text { Grodzieckie. }\end{array}$ & Infrastruktura drogowa & 2725000,00 & 1362500,00 \\
\hline & Budowa sali sportowej przy gimnazjum w miejscowości Rychwal. & $\begin{array}{l}\text { Infrastruktura i usługi spo- } \\
\text { leczne }\end{array}$ & 6830122,42 & 2745086,03 \\
\hline & $\begin{array}{l}\text { Przebudowa budynków dawnej mleczarni wraz z adaptacją na Cen- } \\
\text { trum Kultury im. Juliusza Kossaka w miejscowości Rychwał. }\end{array}$ & Turystyka i kultura & 3921551,47 & 2745086,03 \\
\hline & Przebudowa drogi gminnej w miejscowości Jaroszewice Rychwalskie. & Infrastruktura drogowa & 1198065,77 & 599032,88 \\
\hline
\end{tabular}




\begin{tabular}{|c|c|c|c|c|}
\hline Gmina & Nazwa projektu & Kategoria zadań & $\begin{array}{l}\text { Wartość } \\
\text { projektu } \\
(\mathrm{w} \mathrm{zl})\end{array}$ & $\begin{array}{l}\text { Wartość wniosko- } \\
\text { wanego dofinan- } \\
\text { sowania (w zl) }\end{array}$ \\
\hline Rzgów & Przebudowa drogi gminnej Slawsk-Branno. & Infrastruktura drogowa & 1080403,72 & 540201,86 \\
\hline \multirow[t]{2}{*}{ Skulsk } & Nadbudowa gimnazjum w Skulsku. & Infrastruktura i usługi spoleczne & 569906,04 & 427429,53 \\
\hline & $\begin{array}{l}\text { Przebudowa drogi gminnej nr G447024 na odcinku Mielnica Duża- } \\
\text { Mielnica Mala. }\end{array}$ & Infrastruktura drogowa & 370823,04 & 185411,52 \\
\hline \multirow[t]{3}{*}{ Sompolno } & Budowa drogi gminnej nr G4052 Stefanowo-Łagiewniki Górne & Infrastruktura drogowa & 1367635,22 & 683817,61 \\
\hline & $\begin{array}{l}\text { Restauracja zabytkowego dawnego ratusza miejskiego wraz z dobu- } \\
\text { dową sali widowiskowej na działalność MGOK przy placu Wolności } \\
26 \text { w Sompolnie. }\end{array}$ & Turystyka i kultura & 5787095,51 & 4016080,71 \\
\hline & Rozbudowa oczyszczalni ścieków przy ul. Blankowej w Sompolnie. & Ochrona środowiska & 6534459,11 & 4047313,62 \\
\hline \multirow{6}{*}{$\begin{array}{l}\text { Stare } \\
\text { Miasto }\end{array}$} & Budowa sali sportowej w miejscowości Lisiec Wielki. & Infrastruktura i uslugi spoleczne & 7195640,00 & 5396730,00 \\
\hline & Budowa sieci kanalizacji sanitarnej w miejscowości Stare Miasto. & Ochrona środowiska & 2734017,31 & 1889361,54 \\
\hline & Przebudowa drogi gminnej nr 482014 P na odcinku Żdżary-Krągola. & Infrastruktura drogowa & 2211707,21 & 1105853,60 \\
\hline & $\begin{array}{l}\text { Przebudowa i rozbudowa oczyszczalni ścieków w miejscowości } \\
\text { Modla Królewska. }\end{array}$ & Ochrona środowiska & 9822466,82 & 5021982,57 \\
\hline & $\begin{array}{l}\text { Uzbrojenie terenów aktywizacji gospodarczej w miejscowości Żdżary } \\
\text { i Kragola. }\end{array}$ & Infrastruktura drogowa & 2151736,40 & 1334115,10 \\
\hline & Z kulturą na ty - organizacja wydarzeń kulturalnych w gminie Stare Miasto. & Turystyka i kultura & 127433,45 & 104789,87 \\
\hline \multirow[t]{4}{*}{ Ślesin } & $\begin{array}{l}\text { Budowa ciągu spacerowo-rowerowego z dostępem do hoteli nad } \\
\text { Jeziorem Slesińskim w ramach Wielkiej Pętli Wielkopolski - etap II. }\end{array}$ & Turystyka i kultura & 4293939,15 & 2200641,26 \\
\hline & Budowa drogi gminnej - obwodnicy miejscowości Honoratka. & Infrastruktura drogowa & 3926292,30 & 1560146,15 \\
\hline & Budowa przystani wodnej w Ślesinie. & Turystyka i kultura & 3008025,55 & 1946372,00 \\
\hline & Modernizacja i remont drogi gminnej w miejscowości Honoratka. & Infrastruktura drogowa & brak danych & 1047209,83 \\
\hline \multirow{2}{*}{$\begin{array}{l}\text { Wierzbi- } \\
\text { nek }\end{array}$} & Przebudowa drogi gminnej Noć-Broniszewo nr 451000. & Infrastruktura drogowa & 767253,06 & 383016,53 \\
\hline & $\begin{array}{l}\text { Przebudowa i remont budynków Zespołu Gimnazjalno-Szkolnego } \\
\text { w Morzyczynie. }\end{array}$ & $\begin{array}{l}\text { Infrastruktura i usługi spo- } \\
\text { leczne }\end{array}$ & 1104133,38 & 784163,53 \\
\hline \multirow[t]{3}{*}{ Wilczyn } & $\begin{array}{l}\text { Remont drogi gminnej w miejscowości Wturek-Głęboczek-Ościsło- } \\
\text { wo-Biela. }\end{array}$ & Infrastruktura drogowa & 939913,75 & 469956,87 \\
\hline & Rewitalizacja terenu Gminnego Ośrodka Sportu i Rekreacji w Wilczynie. & Turystyka i kultura & 2288754,06 & 1481607,82 \\
\hline & Termomodernizacja obiektów użyteczności publicznej w gminie Wilczyn. & Infrastruktura i usługi spoleczne & 1706936,91 & 1401293,38 \\
\hline
\end{tabular}

Źródło: opracowanie własne na podstawie danych SIMIK oraz informacji z urzędów gmin. 
ly prawie wszystkie gminy powiatu konińskiego (wyjątek stanowiła tylko gmina Krzymów) - Kramsk, Rychwał, Stare Miasto i Ślesin złożyły po dwa wnioski o dofinansowanie, zaś pozostałe po jednym wniosku. Biorąc pod uwagę kwotę wnioskowanego wsparcia projektów z tej kategorii zadań i odnosząc ją do ogólnej wartości wnioskowanego dofinansowania $z$ WRPO, można stwierdzić, że ich realizacja miała największe znaczenie dla gmin: Grodziec i Rzgów, które swoje starania pozyskania środków z WRPO ukierunkowały wyłącznie na inwestycje drogowe co może oznaczać, że ich realizacja była dla nich priorytetem. Pozyskanie środków na zadania $\mathrm{z}$ zakresu infrastruktury drogowej odgrywało dużą rolę także w gminach: Kazimierz Biskupi i Kramsk, w których kwota wnioskowanego wsparcia stanowiła kolejno: 63,1\% i 55,6\% ogólnej kwoty wnioskowanego dofinansowania. W przypadku pozostałych badanych

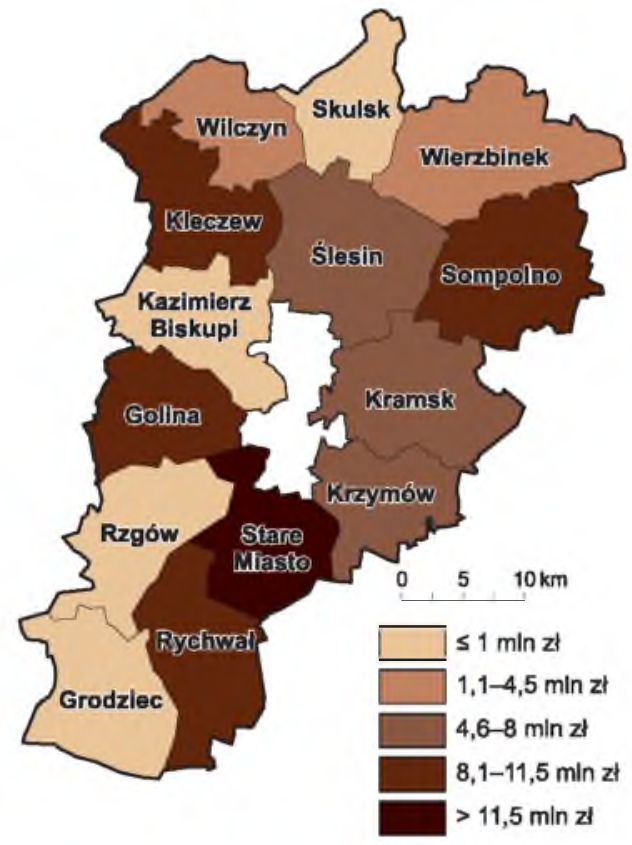

Ryc. 1. Aktywność gmin powiatu konińskiego $\mathrm{w}$ pozyskiwaniu środków z WRPO w latach 2007-2013 (wartość wniosków złożonych do konkursów w mln zł)

Źródło: opracowanie własne na podstawie danych SIMIK oraz informacji z urzędów gmin. samorządów lokalnych udział ten kształtował się na niższym poziomie. W gminach: Skulsk, Ślesin i Wierzbinek jego wartość oscylowała w granicach 30-40\%, natomiast w gminach: Golina, Kleczew, Rychwał, Sompolno, Stare Miasto i Wilczyn nie przekraczała 20\% (patrz ryc. 2).

Wnioski o dofinansowanie projektów z zakresu ochrony środowiska stanowiły 17,9\% ogólnej liczby złożonych przez gminy powiatu konińskiego wniosków z WRPO. Kwota dofinansowania, którą starały się one pozyskać na realizację tych zadań, stanowiła 30,3\% ogólnej wartości wnioskowanego przez nie wsparcia z WRPO. Wnioski o dofinansowanie działań związanych z ochroną środowiska (głównie na budowę kanalizacji i oczyszczalni ścieków) złożyło pięć gmin badanego powiatu: Kazimierz Biskupi, Kleczew, Krzymów, Sompolno i Stare Miasto, przy czym Kazimierz Biskupi i Stare Miasto złożyły po dwa wnioski, a pozostałe po jednym wniosku o dofinansowanie. Realizacja projektów z dziedziny ochrony środowiska miała największe znaczenie dla gminy Krzymów, która starała się pozyskać środki z WRPO wyłącznie na inwestycje $z$ tego zakresu. Stosunkowo wysoki udział wnioskowanej kwoty dofinansowania na działania z tej kategorii zadań w ogólnej kwocie wnioskowanego wsparcia odnotowano też w gminie Kleczew, w której osiągnął on wartość 59,0\%. W pozostałych badanych jednostkach 


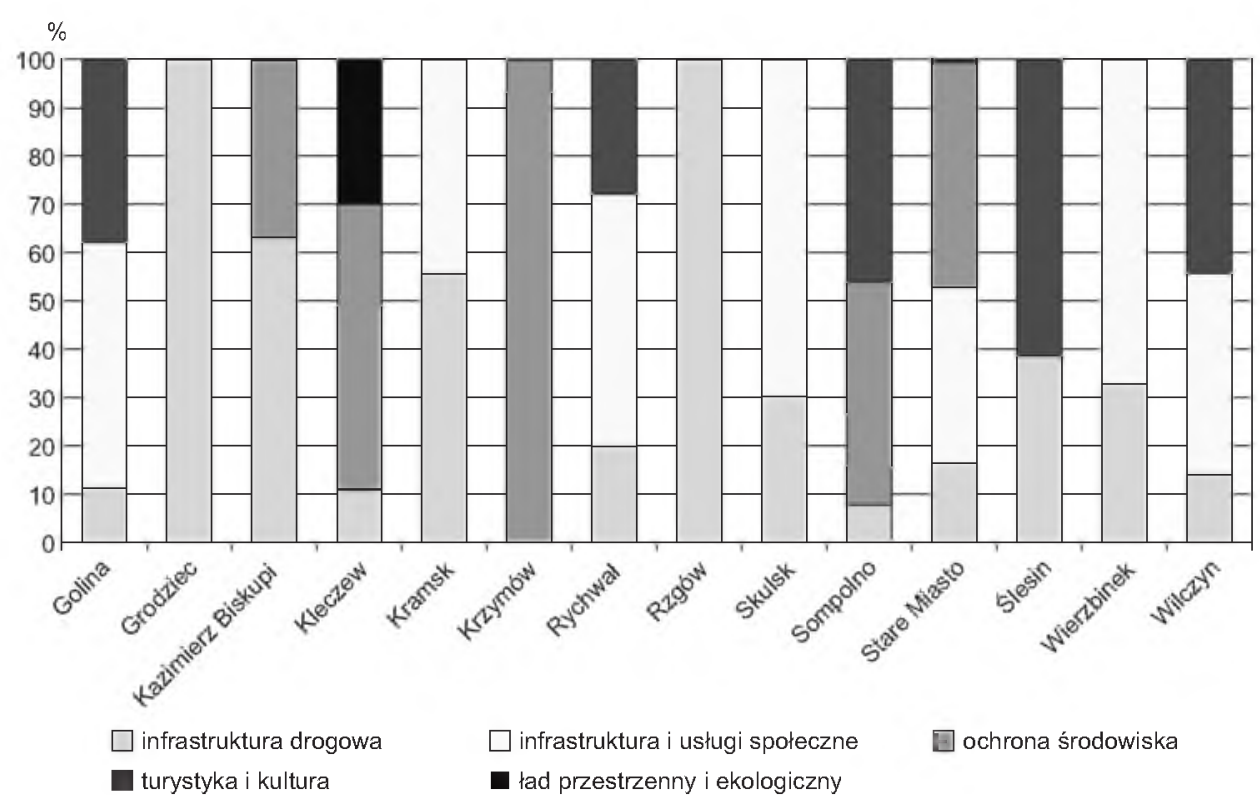

Ryc. 2. Struktura złożonych przez gminy powiatu konińskiego wniosków o dofinansowanie z WRPO w latach 2007-2013 według kategorii zadań

Źródło: opracowanie własne na podstawie danych SIMIK oraz informacji z urzędów gmin.

samorządu lokalnego: Stare Miasto, Sompolno i Kazimierz Biskupi udział ten nie przekraczał poziomu 50\% - wynosił odpowiednio: 46,5\%, 46,3\% i 36,9\%.

W kategorii zadań dotyczących infrastruktury i usług społecznych liczba złożonych wniosków o dofinansowanie stanowiła 17,9\% ogólnej liczby złożonych przez gminy powiatu konińskiego wniosków o wsparcie z WRPO. Kwota, którą starały się one pozyskać, stanowiła natomiast 25,8\% ogólnej kwoty wnioskowanego wsparcia $z$ WRPO. Aktywność w pozyskaniu środków na zadania $z$ tego zakresu (głównie na budowę szkół i sal sportowych) wykazało siedem gmin powiatu konińskiego: Golina, Kramsk, Rychwał, Skulsk, Stare Miasto, Wierzbinek i Wilczyn - złożyły one po jednym wniosku o dofinansowanie. Realizacja projektów z dziedziny infrastruktury i usług społecznych miała największe znaczenie dla gmin: Skulsk i Wierzbinek, w których udział kwoty wnioskowanego dofinansowania tych projektów w ogólnej kwocie wsparcia, o którą ubiegały się one z WRPO, osiągnął wartość odpowiednio: 69,7\% i 67,2\%. Pozyskanie środków na działania z tego zakresu miało duże znaczenie także w gminach: Rychwał i Golina, w których kwota wnioskowanego wsparcia na realizację tych projektów stanowiła odpowiednio: 52,1\% oraz 50,7\% ogólnej wartości wnioskowanego przez nie wsparcia z WRPO. W przypadku pozostałych analizowanych jednostek samorządu terytorialnego: Kramsk, Stare Miasto i Wilczyn udział ten nie przekraczał poziomu 50\% i osiągał wartość kolejno: 44,4\%, 36,3\% oraz 41,8\%.

Złożone przez gminy powiatu konińskiego wnioski o dofinansowanie zadań z obszaru turystyki i kultury stanowiły 17,9\% ogólnej liczby złożonych przez nie wniosków o wsparcie z WRPO. Udział wnioskowanej kwoty dofinansowa- 
nia tych działań w ogólnej kwocie wnioskowanego przez nie wsparcia z WRPO osiągnął natomiast wartość 19,4\%. Środki na realizację projektów turystycznych i kulturowych starało się pozyskać z WRPO pięć gmin powiatu konińskiego: Golina, Rychwał, Sompolno, Stare Miasto, Ślesin i Wilczyn (Ślesin - dwa wnioski o dofinansowanie, pozostałe - po jednym wniosku). Biorąc pod uwagę udzial wartości wnioskowanego dofinansowania na projekty z tego zakresu w ogólnej kwocie wsparcia, o którą ubiegały się one w ramach WRPO, można stwierdzić, że ich realizacja miała największe znaczenie dla gminy Ślesin, w której osiągnął on wartość 61,4\%. Pozyskanie środków na działania związane z turystyką i kulturą odgrywało dużą rolę także w gminach: Sompolno, Wilczyn i Golina, gdzie kwota wnioskowanego dofinansowania stanowiła odpowiednio: 45,9\%, 44,2\% i 37,9\% ogólnej kwoty wsparcia, którą starały się one pozyskać z WRPO. W przypadku pozostałych analizowanych samorządów lokalnych: Rychwał i Stare Miasto, udział ten nie przekraczal poziomu $30 \%$ - wynosił odpowiednio $27,9 \%$ oraz $0,7 \%$.

Gminy powiatu konińskiego wykazały niewielkie zainteresowanie pozyskaniem wsparcia z WRPO na zadania z dziedziny ładu przestrzennego i ekologicznego. Udział liczby złożonych wniosków o dofinansowanie działań z tego zakresu stanowił 2,6\% ogólnej liczby złożonych przez nie wniosków z WRPO, zaś udział wartości wnioskowanego wsparcia na realizację tych projektów w ogólnej kwocie, którą starały się one pozyskać z WRPO, wynosił 3,9\%. Aktywność w tej kategorii zadań wykazała jedynie gmina Kleczew, która złożyła jeden wniosek o dofinansowanie - starała się pozyskać kwotę stanowiącą 30,0\% całkowitej wartości wnioskowanego przez nią wsparcia z WRPO.

\section{Skuteczność gmin powiatu konińskiego w pozyskaniu środków z WRPO}

Skuteczność gmin w pozyskiwaniu środków pochodzących z WRPO określono na podstawie udziału liczby i wartości zrealizowanych przez nie wniosków w ogólnej liczbie i wartości złożonych wniosków, również w odniesieniu do kategorii zadań. W analizie uwzględniono też wartość uzyskanego wsparcia z WRPO przypadającą na jednego mieszkańca.

Gminy powiatu konińskiego, pomimo względnie dużej aktywności, wykazały się relatywnie niską skutecznością w absorpcji środków z WRPO. Spośród 39 złożonych przez nie wniosków dofinansowanie otrzymało zaledwie 16, co oznacza ogólną skuteczność na poziomie 41,0\%. Skuteczność określona udziałem kwoty uzyskanego dofinansowania w ogólnej wartości wnioskowanego wsparcia osiągnęła natomiast poziom $46,4 \%$. W strukturze wewnętrznej badanego powiatu zauważyć można duże zróżnicowanie skuteczności w absorpcji środków z WRPO (patrz tab. 2). Najwyższą (100\%) skutecznością w tym zakresie wykazała się gmina Krzymów - należy jednak pamiętać, że złożyła ona tylko jeden wniosek o dofinansowanie. Względnie wysoki stopień skuteczności cechował także gminy: Kleczew, Wilczyn oraz Kazimierz Biskupi, w których stosunek liczby projektów 
dofinansowanych do wnioskowanych wynosił $66,7 \%$, a pozyskane środki stanowiły odpowiednio: $89,0 \%, 86,0 \%$ oraz 78,3\% ogólnej kwoty wnioskowanego przez nie wsparcia. Gminy: Wierzbinek i Ślesin pozyskały środki na realizację połowy złożonych przez nie wniosków - wartość uzyskanego wsparcia stanowiła natomiast kolejno: 67,2\% i 61,4\% ogólnej kwoty, którą starały się one pozyskać z WRPO. W przypadku gminy Stare Miasto, w której liczba przyjętych do realizacji wniosków obejmowała $66,7 \%$ liczby złożonych wniosków, udział wartości uzyskanego wsparcia w kwocie wnioskowanego dofinansowania wynosił $56,2 \%$. W gminach: Sompolno i Rychwał odnotowano niższą skuteczność w absorpcji środków z WRPO - liczba realizowanych wniosków to kolejno: 33,3\% i 25,0\% ogólnej liczby złożonych przez nie wniosków, zaś stosunek kwoty wsparcia uzyskanego do wnioskowanego wynosił odpowiednio: 46,3\% oraz 6,1\%. W przypadku pozostałych badanych jednostek samorządu terytorialnego: Golina, Grodziec, Kramsk, Rzgów i Skulsk, działania pozyskania środków z WRPO zakończyły się niepowodzeniem.

Wartość uzyskanego dofinansowania w przeliczeniu na jednego mieszkańca, podobnie jak w przypadku skuteczności mierzonej stosunkiem liczby projektów dofinansowanych do wnioskowanych i udziałem kwoty pozyskanego dofinansowania w wartości wnioskowanego wsparcia z WRPO, osiągnęła najwyższy poziom w gminach: Krzymów - 1021,90 zł oraz Kleczew - 980,99 zł. Relatywnie wysoką wartość wskaźnika odnotowała także gmina Stare Miasto, w której kwota otrzy-

Tabela 2. Skuteczność gmin powiatu konińskiego w pozyskiwaniu środków WRPO w latach 2007-2013

\begin{tabular}{|c|c|c|c|c|c|c|}
\hline \multirow[b]{2}{*}{ Gmina } & \multicolumn{2}{|c|}{ Liczba wniosków } & \multirow{2}{*}{$\begin{array}{l}\text { Skuteczność } \\
\quad(w \%)\end{array}$} & \multicolumn{2}{|c|}{ Wartość dofinansowania (w zl) } & \multirow{2}{*}{$\begin{array}{c}\text { Skuteczność } \\
\text { (w \%) }\end{array}$} \\
\hline & $\begin{array}{l}\text { zlożo- } \\
\text { nych }\end{array}$ & $\begin{array}{l}\text { zrealizo- } \\
\text { wanych }\end{array}$ & & wnioskowanego & uzyskanego & \\
\hline Golina & 3 & 0 & 0,0 & 9675588,61 & 0,00 & 0,0 \\
\hline Grodziec & 1 & 0 & 0,0 & 855237,34 & 0,00 & 0,0 \\
\hline $\begin{array}{l}\text { Kazimierz } \\
\text { Biskupi }\end{array}$ & 3 & 2 & 66,7 & 720683,34 & 564549,32 & 78,3 \\
\hline Kleczew & 3 & 2 & 66,7 & 10927035,81 & 9725960,98 & 89,0 \\
\hline Kramsk & 3 & 0 & 0,0 & 7819763,60 & 0,00 & 0,0 \\
\hline Krzymów & 1 & 1 & 100,0 & 7590836,47 & 7590836,47 & 100,0 \\
\hline Rychwał & 4 & 1 & 25,0 & 9829210,72 & 599032,88 & 6,1 \\
\hline Rzgów & 1 & 0 & 0,0 & 540201,86 & 0,00 & 0,0 \\
\hline Skulsk & 2 & 0 & 0,0 & 612841,05 & 0,00 & 0,0 \\
\hline Sompolno & 3 & 1 & 33,3 & 8747211,94 & 4047313,62 & 46,3 \\
\hline Stare Miasto & 6 & 4 & 66,7 & 14852832,68 & 8350249,08 & 56,2 \\
\hline Ślesin & 4 & 2 & 50,0 & 6754369,24 & 4147013,26 & 61,4 \\
\hline Wierzbinek & 2 & 1 & 50,0 & 1167180,06 & 784163,53 & 67,2 \\
\hline Wilczyn & 3 & 2 & 66,7 & 3352858,07 & 2882901,20 & 86,0 \\
\hline Ogólem & 39 & 16 & 41,0 & 83445850,79 & 38692020,34 & 46,4 \\
\hline
\end{tabular}

Źródlo: opracowanie własne na podstawie danych SIMIK oraz informacji z urzędów gmin. 
manego wparcia przypadająca na mieszkańca wynosiła 747,63 zl. Niższą wartość wskaźnika, nieprzekraczającą poziomu 500 zł, osiągnęły: Wilczyn, Sompolno i Ślesin, w których wynosiła ona kolejno: 453,05 zł, 384,90 zł i 300,16 zł. W przypadku pozostałych analizowanych samorządów terytorialnych kwota pozyskanego wsparcia z WRPO w przeliczeniu na mieszkańca osiągnęła niższy poziom. W gminach: Wierzbinek i Rychwał kształtowała się ona na poziomie odpowiednio: 103,34 zł i 71,57 zł, natomiast dla gminy Kazimierz Biskupi, charakteryzującej się względnie wysoką skutecznością mierzoną stosunkiem projektów zrealizowanych do wnioskowanych oraz udziałem wartości uzyskanego wsparcia w kwocie wnioskowanego dofinansowania z WRPO, wskaźnik osiągnął relatywnie niską wartość - 51,18 zł. Pozostałe badane jednostki samorządu lokalnego nie pozyskały w latach 20072013 funduszy z WRPO, tym samym wartość wskaźnika wynosiła 0.

W układzie kategorii zadań skuteczność gmin powiatu konińskiego w absorpcji środków z WRPO wykazała pewne różnice. Najniższą skuteczność odnotowano w odniesieniu do zadań dotyczących infrastruktury drogowej. Spośród 17 złożonych przez gminy wniosków tylko trzy uzyskały dofinansowanie z WRPO, co oznacza skuteczność na poziomie 17,6\%. Skuteczność określona udziałem środków otrzymanych na wykonanie tych zadań w ogólnej kwocie wnioskowanego wsparcia z WRPO wynosiła $13,9 \%$. Wśród badanych jednostek samorządu terytorialnego dofinansowanie na działania z zakresu infrastruktury drogowej otrzymały trzy: Kazimierz Biskupi, Rychwał oraz Stare Miasto (patrz tab. 3). Gmina Kazimierz Biskupi wykazała się pełną skutecznością w absorpcji środków na realizację projektów drogowych, natomiast w gminach: Rychwał i Stare Miasto skuteczność określona stosunkiem liczby realizowanych wniosków do liczby wniosków złożonych w tej kategorii zadań wynosiła 50,0\%, zaś skuteczność mierzona udziałem wartości uzyskanego wsparcia w kwocie wnioskowanego dofinansowania wynosiła odpowiednio: $30,5 \%$ oraz $54,7 \%$.

W latach 2007-2013 gminy powiatu konińskiego charakteryzowały się względnie niską skutecznością w pozyskiwaniu środków z WRPO na realizację projektów z zakresu infrastruktury i usług społecznych. Z siedmiu złożonych przez nie wniosków dofinansowanie uzyskały zaledwie dwa, co oznacza ogólną skuteczność na poziomie $28,6 \%$. Skuteczność określona stosunkiem wartości pozyskanego wsparcia do całkowitej kwoty dofinansowania, którą starały się one pozyskać w tej kategorii zadań z WRPO, kształtowała się na poziomie 11,4\%. Dofinansowanie na realizację projektów z zakresu infrastruktury i usług społecznych otrzymały dwie gminy badanego powiatu: Wierzbinek oraz Wilczyn, które w tej kategorii zadań wykazały się pełną (100\%) skutecznością.

Wyższą skuteczność pozyskiwania środków z WRPO odnotowano wśród gmin powiatu konińskiego w odniesieniu do zadań z zakresu turystyki i kultury. Spośród siedmiu złożonych przez nie wniosków dofinansowanie otrzymały cztery, tym samym ich skuteczność wynosiła 57,1\%. Biorąc pod uwagę wartość uzyskanych funduszy i odnosząc ją do ogólnej kwoty, którą starały się one pozyskać w tej kategorii zadań, należy stwierdzić, że skuteczność osiągnęła wartość 35,5\%. Dofinansowanie na realizację projektów z obszaru turystyki i kultury otrzymały 
Tabela 3. Projekty realizowane przez gminy powiatu konińskiego w ramach WRPO w latach 2007-2013

\begin{tabular}{|c|c|c|}
\hline Gmina & Nazwa projektu & Kategoria zadań \\
\hline Golina & - & - \\
\hline Grodziec & - & - \\
\hline \multirow{2}{*}{$\begin{array}{l}\text { Kazimierz } \\
\text { Biskupi }\end{array}$} & Przebudowa drogi Wola Łaszczowa-Sokółki. & Infrastruktura drogowa \\
\hline & $\begin{array}{l}\text { Wyposażenie Centrum Edukacji Ekologicznej o Pusz- } \\
\text { czy Bieniszewskiej w Kazimierzu Biskupim. }\end{array}$ & Ochrona środowiska \\
\hline \multirow[t]{2}{*}{ Kleczew } & $\begin{array}{l}\text { Budowa oczyszczalni ścieków i kanalizacji sanitarnej } \\
\text { w Kleczewie. }\end{array}$ & Ochrona środowiska \\
\hline & $\begin{array}{l}\text { Rewitalizacja terenów pogórniczych wokół jeziora } \\
\text { w gminie Kleczew. }\end{array}$ & $\begin{array}{l}\text { Ead przestrzenny i eko- } \\
\text { logiczny }\end{array}$ \\
\hline Kramsk & - & - \\
\hline Krzymów & $\begin{array}{l}\text { Budowa kanalizacji sanitarnej części zachodniej aglo- } \\
\text { meracji Krzymów. }\end{array}$ & Ochrona środowiska \\
\hline Rychwał & $\begin{array}{l}\text { Przebudowa drogi gminnej w miejscowości Jaroszewi- } \\
\text { ce Rychwalskie. }\end{array}$ & Infrastruktura drogowa \\
\hline Rzgów & - & - \\
\hline Skulsk & - & - \\
\hline Sompolno & $\begin{array}{l}\text { Rozbudowa oczyszczalni ścieków przy ul. Błankowej } \\
\text { w Sompolnie. }\end{array}$ & Ochrona środowiska \\
\hline \multirow[t]{4}{*}{ Stare Miasto } & $\begin{array}{l}\text { Budowa sieci kanalizacji sanitarnej w miejscowości } \\
\text { Stare Miasto. }\end{array}$ & Ochrona środowiska \\
\hline & $\begin{array}{l}\text { Przebudowa i rozbudowa oczyszczalni ścieków w miej- } \\
\text { scowości Modła Królewska. }\end{array}$ & Ochrona środowiska \\
\hline & $\begin{array}{l}\text { Uzbrojenie terenów aktywizacji gospodarczej w miej- } \\
\text { scowości Żdżary i Krągola. }\end{array}$ & Infrastruktura drogowa \\
\hline & $\begin{array}{l}\text { Z kulturą na ty - organizacja wydarzeń kulturalnych } \\
\text { w gminie Stare Miasto. }\end{array}$ & Turystyka i kultura \\
\hline \multirow[t]{2}{*}{ Ślesin } & $\begin{array}{l}\text { Budowa ciagu spacerowo-rowerowego z dostępem } \\
\text { do hoteli nad Jeziorem Ślesińskim w ramach Wielkiej } \\
\text { Pętli Wielkopolski - etap II. }\end{array}$ & Turystyka i kultura \\
\hline & Budowa przystani wodnej w Ślesinie. & Turystyka i kultura \\
\hline Wierzbinek & $\begin{array}{l}\text { Przebudowa i remont budynków Zespołu Gimnazjal- } \\
\text { no-Szkolnego w Morzyczynie. }\end{array}$ & $\begin{array}{l}\text { Infrastruktura i usługi } \\
\text { spoleczne }\end{array}$ \\
\hline \multirow[t]{2}{*}{ Wilczyn } & $\begin{array}{l}\text { Rewitalizacja terenu Gminnego Ośrodka Sportu i Re- } \\
\text { kreacji w Wilczynie. }\end{array}$ & Turystyka i kultura \\
\hline & $\begin{array}{l}\text { Termomodernizacja obiektów użyteczności publicznej } \\
\text { w gminie Wilczyn. }\end{array}$ & $\begin{array}{l}\text { Infrastruktura i usługi } \\
\text { spoleczne }\end{array}$ \\
\hline
\end{tabular}

Źródło: opracowanie własne na podstawie danych SIMIK oraz informacji z urzędów gmin.

trzy gminy badanego powiatu: Stare Miasto, Ślesin oraz Wilczyn, które w tej kategorii zadań wykazały się pełną skutecznością podjętych działań.

Gminy powiatu konińskiego osiągnęly wysoką skuteczność w pozyskiwaniu funduszy z WRPO na realizację zadań związanych z ochroną środowiska. Spośród siedmiu złożonych przez nie wniosków o dofinansowanie tylko jeden nie został zrealizowany, tym samym ich skuteczność w tej kategorii zadań wynosiła 85,7\%. Skuteczność mierzona udziałem kwoty uzyskanego dofinansowania w ogólnej 
kwocie wnioskowanego wsparcia z WRPO na realizację projektów z tego zakresu wynosiła 99,4\%. Wśród gmin powiatu konińskiego ubiegających się o środki z WRPO na projekty z zakresu ochrony środowiska, Kleczew, Krzymów, Sompolno oraz Stare Miasto osiągnęły 100-procentową skuteczność ich pozyskania, natomiast Kazimierz Biskupi - 50-procentową skuteczność mierzoną udziałem liczby zrealizowanych wniosków $w$ ogólnej liczbie wniosków złożonych w tej kategorii zadań i 41,2-procentową skuteczność określoną udziałem wartości otrzymanego dofinansowania w ogólnej kwocie wnioskowanego przez nią wsparcia z WRPO.

W kategorii zadań dotyczących ładu przestrzennego i ekologicznego gmina Kleczew, która jako jedyna wśród badanych samorządów terytorialnych złożyła wniosek o wsparcie projektu z tego zakresu, wykazała się pełną skutecznością w pozyskaniu środków z WRPO na jego realizację.

\section{Podsumowanie}

Przeprowadzona analiza pozwala stwierdzić, że aktywność gmin powiatu konińskiego w pozyskiwaniu środków z WRPO charakteryzowała się w latach 20072013 dużym zróźnicowaniem. Wśród badanych jednostek samorządu lokalnego znacząco wyróżniała się gmina Stare Miasto, która złożyła największą liczbę wniosków o dofinansowanie, a przez to starała się pozyskać najwyższą kwotę wsparcia. $Z$ drugiej strony zidentyfikowano także gminy, które podjęły niewielkie starania o pozyskanie środków z WRPO na realizację projektów, wśród których wymienić można m.in. Grodziec i Rzgów (złożyły one po jednym wniosku o stosunkowo niedużej wartości). Aktywność gmin powiatu konińskiego w absorpcji środków z WRPO kształtowała się na różnym poziomie w poszczególnych kategoriach zadań. Na podstawie złożonych przez nie wniosków można stwierdzić, że byly one zainteresowane przede wszystkim pozyskaniem środków na realizację projektów mających na celu uzupełnienie istniejących braków infrastrukturalnych. Priorytetem były projekty dotyczące infrastruktury drogowej, na których realizację złożyły one największą liczbę wniosków o dofinansowanie - co może świadczyć o ogromnych potrzebach w tym zakresie. Duże znaczenie miało także otrzymanie wsparcia na zadania $z$ dziedziny ochrony środowiska, których realizacja wymagała poniesienia wysokich kosztów, przekraczających najczęściej możliwości finansowe samorządów. Gminy powiatu konińskiego wykazały również zainteresowanie zdobyciem środków na realizację zadań z zakresu infrastruktury i usług społecznych, mających na celu poprawę jakości i dostępności usług społecznych, oraz na projekty turystyczne i kulturowe, w których coraz częściej dostrzegają szansę poprawy poziomu życia ich mieszkańców. Najniższą aktywność wśród badanych samorządów lokalnych odnotowano zaś w kategorii zadań dotyczących ładu przestrzennego i ekologicznego - tylko jedna gmina złożyła wniosek o wsparcie takiego projektu.

Aktywność gmin powiatu konińskiego w pozyskiwaniu środków z WRPO nie przełożyła się na skuteczność podjętych przez nie starań - ich ogólna skuteczność 
nie przekroczyła bowiem poziomu 50\%. W strukturze wewnętrznej badanego powiatu stopień skuteczności absorpcji środków z WRPO charakteryzował się dużym zróżnicowaniem. $Z$ jednej strony wskazać można gminy, które wykazały się relatywnie wysoką skutecznością - wśród nich wymienić można: Krzymów, Kleczew oraz Wilczyn, z drugiej strony zidentyfikowano gminy, które pomimo stosunkowo wysokiej aktywności nie osiągnęły założonych planów pozyskania wsparcia z WRPO - m.in. Golina i Kramsk. Stopień skuteczności w pozyskiwaniu środków z WRPO wykazywał duże różnice w poszczególnych kategoriach zadań. Wysoką skuteczność w absorpcji środków odnotowano w zakresie zadań dotyczących ochrony środowiska, a więc inwestycji, na które badane gminy starały się pozyskać najwyższą kwotę dofinansowania, determinującą w dużym stopniu ich realizację. Znacznie niższą skuteczność gmin powiatu konińskiego odnotowano w pozyskiwaniu środków z WRPO na projekty z zakresu turystyki i kultury oraz infrastruktury i usług społecznych, zaś najniższą w odniesieniu do projektów drogowych, a więc inwestycji będących dla większości gmin priorytetem.

\section{Literatura}

Churski P. 2008. Czynniki rozwoju regionalnego i polityka regionalna w Polsce w okresie integracji z Unią Europejską. Wydawnictwo Naukowe UAM, Poznań.

Churski P. 2014. Wpływ funduszy Unii Europejskiej na rozwój Poznania na tle wybranych miast w Polsce - próba bilansu pierwszej dekady członkostwa w Unii Europejskiej. [W:] P. Churski, T. Stryjakiewicz (red.), Poznań - próba bilansu przemian w okresie 10 lat członkostwa w Unii Europejskiej. Rozwój Regionalny i Polityka Regionalna, 27: 25-44.

Jastrzębska M. 2012. Finanse jednostek samorządu terytorialnego. Oficyna a Wolters Kluwer business, Warszawa.

Kuchleweski T., Toloczko A., Sadowska M., Sadowski T. 2007. Fundusze Pomocowe UE. Praktyczny poradnik dla samorządów w okresie 2007-2013. Provent Investment, Kleosin-Ignatki.

Leoński Z. 2002. Samorząd terytorialny w RP. Wydawnictwo C.H. Beck, Warszawa.

Misterek W. 2008. Zewnętrzne źródla finansowania działalności inwestycyjnej jednostek samorządu terytorialnego. Diffin, Warszawa.

Motek P. 2006. Gospodarka finansowa samorządu terytorialnego w województwie wielkopolskim. Bogucki Wydawnictwo Naukowe, Poznań

Niewiadomski Z. (red.), Siemiński W., Sosnowski P., Tetera M. 2001. Samorząd terytorialny. Ustrój i gospodarka. Oficyna Wydawnicza Branta, Warszawa.

Sztorc E., Świstak M., Tkaczyński J.W. 2011. Projekty europejskie. Praktyczne aspekty pozyskiwania i rozliczania dotacji unijnych. Wydawnictwo C.H. Beck, Warszawa.

Ustawa o samorządzie gminnym z dnia 8 marca 1990 roku (Dz.U. z 1990 r. nr 16, poz. 95).

\section{Activity and effectiveness of Konin county municipalities in funds raising from Regional Operational Programme for Wielkopolska in 2007-2013 for the implementation of municipalities own tasks}

\footnotetext{
Abstract: Polish integration with the European Union created for polish municipalities unique opportunity to fill gaps in local budget. Possibilities and benefits of the use UE funds for the implementation of many costly projects caused an increased of interest municipalities their acquire. The aim of the paper is to identify differentiation of activity and effectiveness of Konin county municipalities
} 
in funds raising from the Regional Operational Programme for Wielkopolska (WRPO). The analysis covers the period 2007-2013 and includes 14 municipalities of Konin county. The analysis was carried out in relation to the municipalities own tasks, which allowed to identify main directions of support provided to municipalities under this Operational Programme.

Key words: Regional Operational Programme for Wielkopolska, structural funds, municipal tasks, Konin county 